\title{
Note
}

\section{Growth and mortality parameters of Sillago sihama (Forsskal, 1775) in coastal waters of the Hormozgan Province, Iran}

\author{
MOHSEN SAFAIE, ROGHAYEH ALIZADEH, EHSAN KAMRANI AND MOHAMMAD MOMENI \\ Fisheries Department, Hormozgan University, Bandar Abbas, P. O. Box 3995, IR Iran \\ e-mail:msn_safaie@yahoo.com
}

\begin{abstract}
Monthly total length frequency data of silver sillago Sillago sihama were collected from the coastal waters of Hormozgan Province, Persian Gulf, from July 2011 to July 2012. ELEFAN-I module of FISAT II was used to analyse the length frequency data. The length-weight relationship derived, demonstrated that growth in this species is allometric. The asymptotic length $(\mathrm{L} \infty)$ was estimated as 26 and $30 \mathrm{~cm}$ for males and females, respectively. The growth parameter $\mathrm{K}$ was calculated as $0.46 \mathrm{y}^{-1}$ for males and $0.43 \mathrm{y}^{-1}$ for females. The total mortality, natural mortality and fishing mortality rates estimated were: $3.55,1.09$ and 2.46 for males and 3.03, 1.00 and 2.03 for females, respectively. The exploitation rate E being more than 0.50 , indicates $S$. sihama stock is currently being overexploited from the Persian Gulf.
\end{abstract}

Keywords: Growth and mortality parameters, Iran, Persian Gulf, Sillago sihama

Sillago sihama (Forsskal, 1775) is an economically important species that inhabits shallow coastal waters up to a depth of $20 \mathrm{~m}$ and rarely up to $60 \mathrm{~m}$ (Carpenter et al., 1997). In the northern Persian Gulf, they are often caught in hooks and incidentally in shrimp trawls. Earlier studies on S. sihama stock from the region have focused on their food and feeding habits (Taghavi Motlagh et al., 2012) and reproductive characteristics in the southern coast of Iran (Mirzaei et al., 2013). Despite their high fishery potential in the northern Persian Gulf and Sea of Oman, no detailed study has been carried out on the population characteristics of this species in the area. Hence, the present study was undertaken to estimate the important population characteristics of the species viz., asymptotic length $(\mathrm{L} \infty)$, growth coefficient $(\mathrm{K})$, mortality (natural and fishing) rates and exploitation rate (E) which are essential for developing fishery management plans for the resource.

A total of 302 male and 681 female specimens of S. sihama were collected during a period of 13 months (July 2011 to July 2012) from commercial catches landed from coastal waters of the northern Persian Gulf, Iran (Fig. 1). Species was caught by shrimp trawls with $40 \mathrm{~mm}$ mesh at wings and $20 \mathrm{~mm}$ at the cod end. Fishing

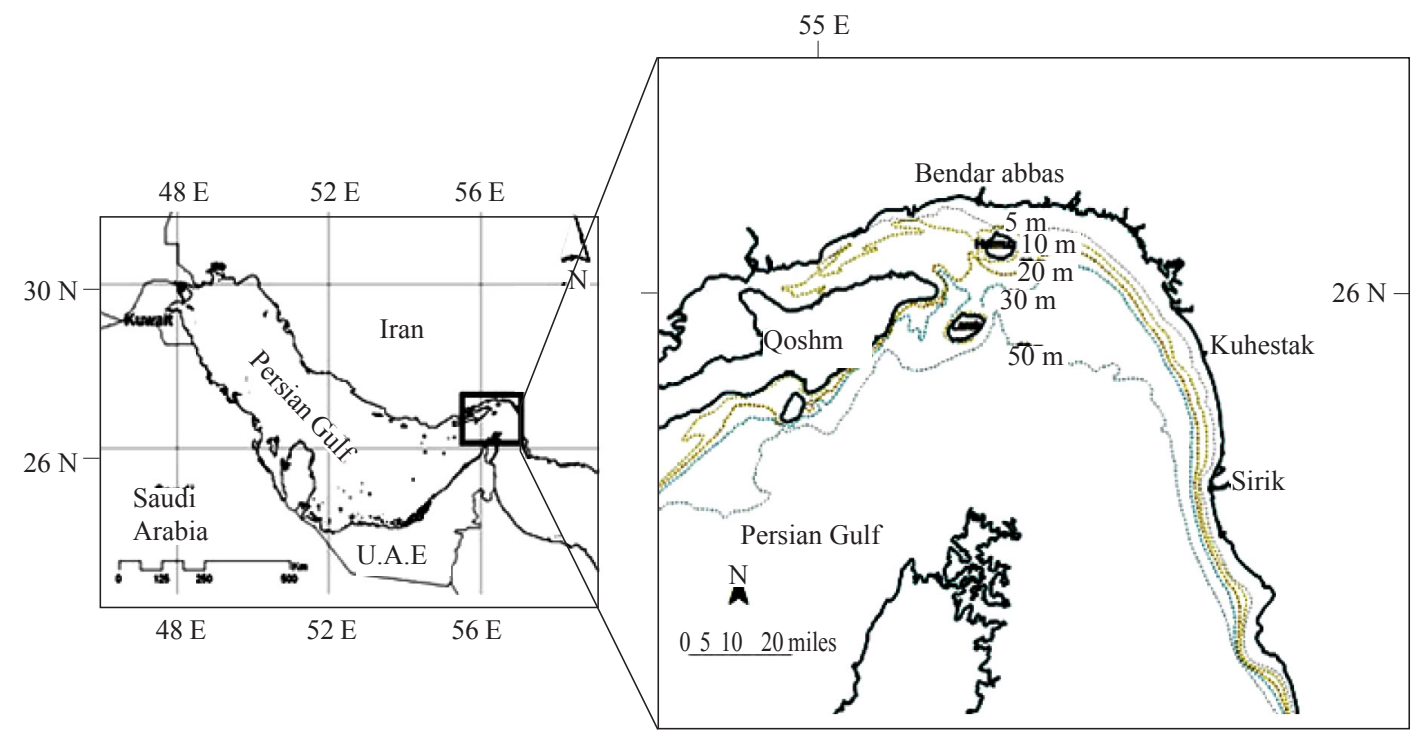

Fig. 1. Study area in the northern Persian Gulf 
area extended from $26^{\circ} 25^{\prime} \mathrm{E}, 57^{\circ} 29^{\prime} \mathrm{N}$ to $27^{\circ} 07^{\prime} \mathrm{E}$, $56^{\circ} 06^{\prime} \mathrm{N}$. Total length of the fish was measured to the nearest $\mathrm{mm}$ from the tip of the snout to the end of the upper caudal lobe and the individual body weight was taken on a physical balance with a precision of $0.01 \mathrm{~g}$.

The relationship between the length and weight was determined by fitting the data to a potential relationship in the form of : $\mathrm{W}=\alpha \mathrm{L}^{\mathrm{b}}$, where $\mathrm{W}$ is the fish weight; $\mathrm{L}$ is the total length; and $\alpha$ and $\mathrm{b}$ are the parameters estimated, with $b$ being the coefficient of allometry (Pauly, 1980). Prior to regression analyses, log-log plots of length and weight values were performed for visual inspection of outliers (Froese, 2006). A linear equation $(\log \mathrm{W}=\log \mathrm{a}+\mathrm{b} \log \mathrm{L})$ was fitted to the $\log$-transformed data. Deviation of the estimated ' $b$ ' value from the isometric value of 3 was tested using t test (Pauly, 1980). Input data were separated by sex and values of $\mathrm{K}$ and $\mathrm{L}_{\infty}$ were estimated for each sex by the von Bertalanffy growth equation:

$\mathrm{Lt}=\mathrm{L}_{\infty}\left(\mathrm{I}-\mathrm{e}^{-\mathrm{K}\left(\mathrm{t}-\mathrm{t}_{0}\right)}\right)$

where, $\mathrm{Lt}$ is the total length at time $\mathrm{t}, \mathrm{L}_{\infty}$ is the asymptotic length $(\mathrm{cm}), \mathrm{K}$ is the growth coefficient $\left(\mathrm{y}^{-1}\right)$, and $\mathrm{t}_{0}$ is the hypothetical age when the size of fish is zero. ELEFAN I module of FISAT II software program was used to estimate the growth parameters from the length frequency data. To find the best growth curve passing through the maximum number of peaks, different starting samples and starting lengths were subjected to goodness-of-fit tests by assessing the ESP/ASP ratio (Rn).

In order to compare the growth of S. sihama from the study area with those from other studies, the growth performance index $\varphi$ was calculated using the formula:

$\varphi=\log K+2^{*} \log L_{\infty}$ (Pauly and Munro, 1984):

The growth parameters obtained from ELEFAN1, were used as input values to estimate the instantaneous rates of total mortality $(Z)$ from length converted catch curve method in the FiSAT II package. The instantaneous rate of natural mortality (M) was obtained using Pauly's empirical formula (1980):

$\ln \mathrm{M}=-0.0152-0.279 \times \ln \mathrm{L}_{\infty}+0.6543 \times \ln \mathrm{K}+0.463 \times \ln \mathrm{T}$

where, $\mathrm{T}$ is the mean water temperature $\left({ }^{\circ} \mathrm{C}\right)$ in the distribution area of S. sihama (taken as $27^{\circ} \mathrm{C}$ ).
The fishing mortality rate (F) was obtained as $\mathrm{F}=\mathrm{Z}-\mathrm{M}$ and the exploitation rate $(\mathrm{E})$ was calculated as $\mathrm{E}=\mathrm{F} / \mathrm{Z}$

The length-weight relationship (Fig. 2) of S. sihama had a high $\mathrm{R}^{2}$ value and the exponent ' $\mathrm{b}$ ' was significantly lower from $3(\mathrm{p}<0.05)$, indicating that growth in this species is negatively allometric. Similar results of allometric growth for this species were reported in south-west coast of India (Annappaswamy et al., 2007), in Zuari Estuary, Goa (Shamsan and Ansari, 2010) and from southern coast of Iran (Mirzaei et al., 2013).

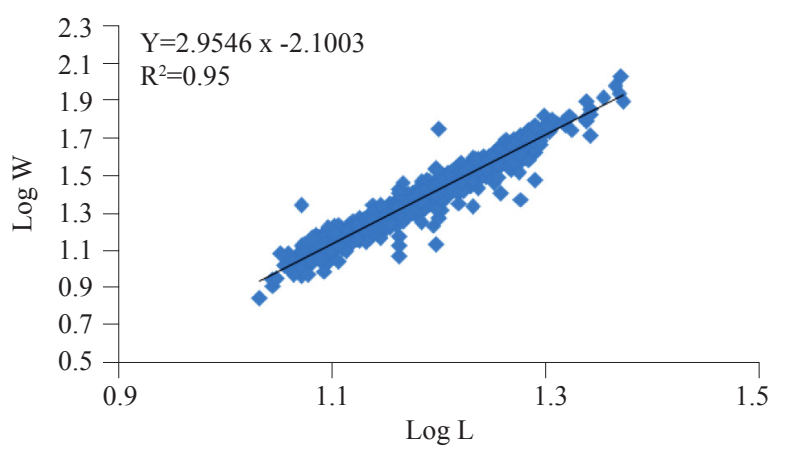

Fig. 2. Length-weight relationship of S. sihama in the Persian Gulf

The growth parameters estimated using male, female and pooled data are shown in Table 1. The values obtained for $\mathrm{K}$ were 0.46 and $0.43 \mathrm{y}^{-1}$ and $\mathrm{L}_{\infty}=26$ and $30 \mathrm{~cm}$ respectively for males and females. The growth performance index $(\varphi)$ of the species estimated was 2.49 for males and 2.59 for females.

The values of $\mathrm{K}$ and $\mathrm{L}_{\infty}$ obtained in this study are close to that estimated for Sillago schomburgkii from Australia (Hyndes and Potter, 1997). Studies on S. sihama from south-west coast of India have also reported differential growth between sexes. $\mathrm{K}$ value for both sexes in this study are higher and $\mathrm{L}_{\infty}$ values are lower than those reported for the species (Annappaswamy et al., 2007; Shamsan and Ansari, 2010).

Mean $\varphi$ values estimated for Sillago spp. in Australia, India and Japan were between 2.36-2.77 for both sexes, and were similar to the findings in this study, suggesting that these estimates of the von Bertalanffy growth parameters are reliable (Table 2). Also, the growth parameters estimated in present study suggest that

Table 1. Growth, mortality and exploitation rates of S. sihama in the Persian Gulf

\begin{tabular}{lllllllll}
\hline Sex & $\mathrm{L}_{\infty}(\mathrm{cm})$ & $\mathrm{K}\left(\mathrm{y}^{-1}\right)$ & $\mathrm{Rn}$ & $\mathrm{T}_{0}$ & $\mathrm{Z}\left(\mathrm{y}^{-1}\right)$ & $\mathrm{M}\left(\mathrm{y}^{-1}\right)$ & $\mathrm{F}\left(\mathrm{y}^{-1}\right)$ & $\mathrm{E}$ \\
\hline Male & 26 & 0.46 & 0.336 & -0.37 & 3.55 & 1.09 & 2.46 & 0.69 \\
Female & 30 & 0.43 & 0.257 & -0.38 & 3.03 & 1.00 & 2.03 & 0.67 \\
Total & 30 & 0.43 & 0.199 & -0.38 & 3.15 & 1.00 & 2.15 & 0.68 \\
\hline
\end{tabular}


Table 2. Growth parameters of Sillago spp. from different regions

\begin{tabular}{llllllll}
\hline Species & $\varphi$ & $\mathrm{t}_{0}$ & $\mathrm{~K}\left(\mathrm{y}^{-1}\right)$ & $\mathrm{L}_{\infty}(\mathrm{cm})$ & Sex & Region & Reference \\
\hline S. sihama & 2.57 & 0.2745 & 0.2226 & 40.68 & Pooled & India & Krishnamurthy and Kaliyamurthy (1976) \\
S. schomburgkii & 2.71 & -0.22 & 0.49 & 32.47 & Male & Australia & Hyndes and Potter (1997) \\
& 2.77 & -0.16 & 0.53 & 33.33 & female & & \\
S. robusta & 2.37 & -1.272 & $0.479 \pm 0.042$ & $22.2 \pm 0.04^{*}$ & Pooled & Australia & Butcher and Hagedoorn (2003) \\
S. aeolus & 2.49 & -0.58 & 0.70 & $20.96^{* *}$ & Male & Japan & Rahman and Tachihara (2005) \\
& 2.57 & -0.61 & 0.42 & $29.77^{* *}$ & Female & & \\
S. sihama & & -1.14 & 0.16 & $50.09^{* * *}$ & Male & India & Annappaswamy et al. (2007) \\
& & -1.13 & 0.15 & $55.10^{* * *}$ & Female & & \\
S. maculate & 2.61 & -0.09 & 0.70 & $24.04^{*}$ & Male & Australia & Kendall and Gray (2009) \\
& 2.65 & -0.04 & 0.72 & $25.01^{*}$ & Female & & \\
S. sihama & 2.36 & -1.6 & 0.153 & 38.80 & Pooled & India & Shamsan and Ansari (2010) \\
S. sihama & 2.49 & -0.37 & 0.46 & 26.00 & Male & Iran & Present study \\
& 2.59 & -0.38 & 0.43 & 30.00 & Female & & \\
\hline
\end{tabular}

* Fork length, ${ }^{* *}$ Standard length, ${ }^{* * *}$ Total length

S. sihama has a longivity of 6.9-7.4 years in the Persian Gulf. In Japanese waters, the longevity of the species Sillago aeolus is 3 years (Rahman and Tachihara, 2005), while for S. schomburgkii in Australian waters it is 4-7 years (Hyndes and Potter, 1997). Differences in ecological conditions due to latitudinal differences can have impact on the value of $\mathrm{K}$ and $\mathrm{L}_{\infty}$ (King, 2007).

Total mortality rates $(Z)$ were 3.55 and $3.03 \mathrm{y}^{-1}$ and fishing mortality rate $(\mathrm{F})$ were 2.46 and $2.03 \mathrm{y}^{-1}$ for males and females respectively. The natural mortality rate (M) for males and females of S. sihama were 1.09 and $1.00 \mathrm{y}^{-1}$ respectively. Natural mortality is related to life history pattern and longevity in the approach of stock assessment (King, 2007; Sparre and venema, 1998). Many environmental factors such as predation, disease, parasitism, and other natural causes act to survival of individuals during their life span and so the values of natural mortality may change accordingly (Allen and Hightower, 2010). Fishing mortality (F) is affected from fishing effort and catchability coefficient (Sparre and Venema, 1998) and the value of $F$ may be different for different fishing areas or at different times in the same fishing area.

Total mortality, natural mortality and fishing mortality rates of $S$. sihama were higher for males than females. The estimated natural and fishing mortality rates of S. sihama for both sexes in this study are higher than the values reported for $S$. sihama in south-west coast of India (Annappaswamy et al., 2007) and for S. robusta in southern Queensland, Australia (Butcher and Hagedoorn, 2003). The exploitation rate (E) was 0.69 for males and 0.67 for females (Table 1). The exploitation rate (E) for both sexes indicate that $S$. sihama stock is currently being overexploited in the Persian Gulf.

\section{Acknowledgements}

We would like to thank Dr. Mortazavi, Iranian Fisheries Research Organisation for providing sampling opportunities and also grateful to several members of the fishing cooperative at Hormozgan Province for their cooperation and assistance during sampling.

\section{References}

Allen, M. S. and Hightower, J. E. 2010. Fish population dynamics: Mortality, growth, and recruitment. In: Hubert, W. A. and Quist, M. C. (Eds.), Inland fisheriues management in North America, $3^{\text {rd }}$ edn. American Fisheries Society, p. 43-79.

Annappaswamy, T. S., Reddy, H. R. V. and Nagesh, T. S. 2007. Age and growth of Sillago sihama (Forskal, 1775) from estuaries of Dakshina Kannada along the south-west coast of India, J. Inland Fish. Soc. India, 39(2): 16-22.

Butcher, A. R. and Hagedoorn, W. L. 2003. Age, growth and mortality estimates of stout whiting Sillago sihama Stead (Sillaginidae) from Southern Queensland, Australia. Asian Fish. Sci., 6: 215-228.

Carpenter, K. E., Krupp, F., Jones D. A. and Zajonz, U. 1997. FAO species identification guide for fishery purposes. The living marine resources of Kuwait, Eastern Saudi Arabia, Bahrain, Qatar and the United Arab Emirates. Rome, FAO, 293 pp.

Rahman, M. D. and Tachihara, K. 2005. Age and growth of Sillago aeolus in Okinawa Island, Japan, J. Oceanogr., 61: 569-573.

Hyndes, G. A. and Potter, I. C. 1997. Age, growth and reproduction of Sillago schomburgkii in south-western Australian, nearshore waters and comparisons of life history styles of a suite of Sillago species. Env. Biol. Fishes, 49: 435-447. 
Kendall, B. W. and Gray, C. A. 2009. Reproduction, age and growth of Sillago maculata in south-eastern Australia, J. Appl. Ichthyol., 25: 529-536.

King, M. 2007. Fisheries biology assessment and management. Fishing News Press, 340 pp.

Krishnamurthy, K. N and Kaliyamurthy, M. 1976. Studies on the age and growth of Indian sand whiting, Sillago sihama (Forsskal) from Pulicat Lake with observations on its biology and fishery. Indian J.Fish., 25: 84-97.

Mirzaei, M. R., Valinasab T., Yasin, Z. and Shau Hwai, A. T. 2013. Reproduction characteristics and length-weight relationships of the sand whiting (Sillago sihama) in the south coast of Iran (Persian Gulf and Oman Sea). Annals Biol. Res., 4(5): 269-278.

Pauly, D. 1980. On the interrelationships between natural mortality, growth parameters and mean environmental temperature in 175 fish stocks. Journal du Conceal International pour 1 Exploration de la mer., 39(2): 175-192.

Pauly, D. 1984. Fish population dynamics in tropical waters: a manual for use with programmable calculators. ICLARM Studies Rev., 8: 325 pp.

Pauly, D. and Munro, J. L. 1984. Once more on the growth comparison in fish and invertebrates. Fishbyte, 2: $21 \mathrm{pp}$.

Shamsan, E. F. and Ansari, Z. A. 2010. Studies of age and growth of Indian sand whiting, Sillago sihama (Forsskal) from Zuari Estuary, Goa. Indian J. Mar. Sci., 39(1): 68-73.

Sparre, P. and Venema, S. C. 1998. Introduction to tropical fish stock assessment, Part 1. FAO Fisheries technical paper, No. 306.1, Rev. 2. FAO, Rome, 407 pp.

Taghavi Motlagh, A., Hakimelahi, M., Ghodrati Shojaei, M., Vahabnezhad, A. and Taheri Mirghaed, A. 2012. Feeding habits and stomach contents of silver sillago, Sillago sihama in the northern Persian Gulf. Iranian J. Fish. Sci., 11(4): 892-901. 